\title{
The Impact of Aluminum-Containing Set Accelerators on Sulfate Resistance of Portland Cement Compositions
}

\author{
Alexey S. Brykov $^{1 *}$, Andrey S. Vasiliev ${ }^{1}$, Maxim V. Mokeev ${ }^{2}$ \\ ${ }^{1}$ Department of Technology of Constructional and Special Binders, Faculty of Chemistry of Substances and Materials, Saint Peters- \\ burg State Institute of Technology, Saint Petersburg, Russia; ${ }^{2}$ Institute of Macromolecular Compounds, Russian Academy of Sci- \\ ences, Saint Petersburg, Russia. \\ Email: "brykov@yahoo.com, Andrey.Vasilev@mc-bauchemie.ru,maxim@hq.macro.ru
}

Received September $28^{\text {th }}, 2013$; revised November $5^{\text {th }}, 2013$; accepted November $27^{\text {th }}, 2013$

Copyright (C) 2013 Alexey S. Brykov et al. This is an open access article distributed under the Creative Commons Attribution License, which permits unrestricted use, distribution, and reproduction in any medium, provided the original work is properly cited.

\begin{abstract}
This study contains comparative research of sulfate resistance of ordinary Portland cement pastes with addition of basic aluminum sulfate (hydroxosulfate, $\left.\mathrm{Al}(\mathrm{OH})_{1.78}\left(\mathrm{SO}_{4}\right)_{0.61}\right)$ and amorphous $\mathrm{Al}(\mathrm{OH})_{3}$. Over 3 months of storing in sodium sulfate solution, the most significant expansion and deterioration occur in case of samples with aluminum hydroxide. During sulfate resistance test, the ratio between aluminum nuclei in AFt (ettringite) and AFm phases was studied by ${ }^{27}$ Al-MAS NMR, and the impact of aluminum-containing admixtures on this ratio was specified. In accordance with NMR data, in samples with $\mathrm{Al}(\mathrm{OH})_{3}$, the rate of secondary ettringite formation becomes noticeable after one month of storing in sulfate solution. For samples with $\mathrm{Al}(\mathrm{OH})_{1.78}\left(\mathrm{SO}_{4}\right)_{0.61}$, the rate of elongation and temper of changes in molar ratio between sulfoaluminate phases were comparable with reference samples without admixtures.
\end{abstract}

Keywords: Portland Cement Hydration; Set Accelerator; Basic Aluminum Sulfate; Aluminum Hydroxide; Sulfate Resistance; MAS NMR Spectroscopy

\section{Introduction}

The aluminum-containing set and hardening accelerators are becoming increasingly common as an alternative to alkali-containing accelerators. Alkali-free acceleratorsaluminum hydroxides, sulfates and hydroxosulfates are capable of intense formation of ettringite in the earliest period of Portland cement hydration [1-4]. At the same time, aluminum-containing compounds are known as inhibitors of interaction of reactive aggregates with alkaline pore solution of concrete and prevent the development of ASR [5,6].

In the previous paper [7], it was found that the solution of aluminum hydroxosulfate $\mathrm{Al}(\mathrm{OH})_{1.78}\left(\mathrm{SO}_{4}\right)_{0.61}$ works more efficiently as Portland cement set accelerator relative to amorphous $\mathrm{Al}(\mathrm{OH})_{3}$ due to the more intensive formation of ettringite in the beginning of hydration. Moreover, aluminum hydroxosulfate, unlike $\mathrm{Al}(\mathrm{OH})_{3}$, doesn't essentially reduce the early strength of hardened cement paste, even at high dosages.

At the same time, it is necessary to take into account

"Corresponding author. the contribution of aluminum-containing additives to the total $\mathrm{Al}_{2} \mathrm{O}_{3}$ and $\mathrm{SO}_{3}$ content in cement paste, because it influences the sulfate resistance of mortars and concretes. The resistance of Portland cement compositions to the exposure of sulfate anions is one of the factors of its durability [8].

The purpose of this work is the comparative study of sulfate resistance of hardened cement pastes with additions of aluminum hydroxosulfate and aluminum hydroxide, as well as the study of the processes occurring in cement pastes with these admixtures during sulfate resistance test with using ${ }^{27}$ Al-MAS NMR.

\section{Experimental Part}

Highly dispersed amorphous aluminum hydroxide Geloxal 10 ("Industrias Químicas del Ebro", Spain) with LOI $47.3 \mathrm{wt} \%$ (at $900^{\circ} \mathrm{C}$ ), specific surface area of 17.8 $\mathrm{m}^{2} / \mathrm{g}$ and particle size up to $20 \mu \mathrm{m}$, was used. The same substance was used in preparing aqueous solution of basic aluminum sulfate $\mathrm{Al}(\mathrm{OH})_{1.78}\left(\mathrm{SO}_{4}\right)_{0.61}(15.1 \%$ based on $\mathrm{Al}_{2} \mathrm{O}_{3}$ ). The synthesis of composition was done in accordance with [7]. Before using, the solution was stored 
1 day after preparation.

Portland cement CEM I 42.5 N with the following composition, wt \%: $\mathrm{C}_{3} \mathrm{~S} 52-53, \mathrm{C}_{2} \mathrm{~S} 18-20, \mathrm{C}_{3} \mathrm{~A}+$ $\mathrm{C}_{4} \mathrm{AF} 20$ - 22, gypsum $\left(\mathrm{CaSO}_{4} \cdot 2 \mathrm{H}_{2} \mathrm{O}\right) 3-4$, anhydrite $\left(\mathrm{CaSO}_{4}\right) 1, \mathrm{CaCO}_{3} 2$ was used. According to the data of chemical analysis, the total content of $\mathrm{Al}_{2} \mathrm{O}_{3}$ is $4.9 \mathrm{wt} \%$.

Amorphous $\mathrm{Al}(\mathrm{OH})_{3}$ was mixed with cement in amount of $3 \mathrm{wt} \%$ of cement $\left(1.58 \mathrm{wt} \%\right.$ of $\mathrm{Al}_{2} \mathrm{O}_{3}$ accordingly). Experiments were carried out at constant waterto-solid ratio $(\mathrm{W} /(\mathrm{C}+$ Admixture $)$ ) of 0.27 , corresponded to normal consistency of the reference cement paste (Russian standard GOST 310.3). The solution of basic aluminum sulfate was added to the cement paste with water in amounts of $9 \%$ of the cement weight $(1.36 \%$ of $\mathrm{Al}_{2} \mathrm{O}_{3}$, i.e. approximately at the same dosage as in the case of $\left.\mathrm{Al}(\mathrm{OH})_{3}\right)$; the water contained in basic aluminium sulfate was taken into account to calculate W/C. According to the calculations, the overall ratios of $\mathrm{Al}_{2} \mathrm{O}_{3}$ / $\mathrm{SO}_{3}$ for reference sample and the samples with the addition of basic aluminum sulfate and aluminum hydroxide are respectively $1.71,1.50$ and 2.25 .

Superplasticizer Melflux 2651F was used in an amount of $0.1 \mathrm{wt} \%$ of cement, which was dissolved in the water of mixing preliminary.

The obtained cement pastes were placed into prism forms of $20 \times 20 \times 100 \mathrm{~mm}$. The forms were stored above water in a tightly closed container at $20^{\circ} \mathrm{C} \pm 2{ }^{\circ} \mathrm{C}$ for 3 days. After that, samples were demolded. One part of samples of each series was stored in distilled water and another part-in sulfate solution $\left(5 \% \mathrm{Na}_{2} \mathrm{SO}_{4}\right)$. Replacement of sodium sulfate solution has been produced monthly. Measurement of expansion (in relative to initial length of samples) was made at 1 and 3 months.

For ${ }^{27} \mathrm{Al}-\mathrm{MAS}$ NMR analysis, the same compositions were made as $30 \times 30 \times 30 \mathrm{~mm}$ cube samples (4 samples of each series). The storage conditions were similar to ones for prism samples. At certain stages of hydration (1 and 28 days, 3 and 6 months) a sample was powdered and a little amount of powder was washed with acetone $(3 \times 30 \mathrm{~mL})$ to remove free water and then was dried under vacuum at ambient temperature.

High-resolution ${ }^{27}$ Al-MAS NMR spectra have been obtained using AVANCE II-500WB (Bruker) spectrometer with "magic angle" rotation. Operating frequency for ${ }^{27} \mathrm{Al} 130,32 \mathrm{MHz}$. Spectra were recorded by singlepulse excitation, the pulse duration $0.7 \mu \mathrm{s}(\pi / 12)$ with a delay of $0.5 \mathrm{sec}$, the number of scans 2048 . The samples $(\sim 100 \mathrm{mg})$ were packaged in zirconia rotors (D 4 $\mathrm{mm})$ and rotated at $13 \mathrm{kHz}$. Chemical shifts are given in ppm relative to $\mathrm{AlCl}_{3} \cdot 6 \mathrm{H}_{2} \mathrm{O}$. The assignment of the signals is accomplished in accordance with the published data [9-11]. The deconvolution of spectra was realised by using software Dmfit.
A NMR spectrum of aqueous basic aluminum sulfate (with addition of $\mathrm{D}_{2} \mathrm{O}$ to adjust the resolution and stabilization) has been received by AVANCE-400 spectrometer (Bruker). The operating frequency for ${ }^{27} \mathrm{Al}$ was $104,26 \mathrm{MHz}$

\section{Results and Discussion}

The results of expansion test are shown in Figure 1.

Figures 2-5 show the ${ }^{27}$ Al-MAS NMR spectra of cement pastes with and without admixtures at various exposure times in the range of chemical shift values of 0 25 ppm (i.e. in the region characteristic of the aluminum ions in coordination VI). The values of integral intensity of signals are shown in the Table 1; the highest intensity is taken to be 100 .

As can be seen from Figure 1, the values of the elongation of samples with basic aluminum sulfate, in aqueous and sulfate environments, are similar to the elongation values of the reference samples. In the period between 1 and 3 months, expansion of the samples did not vary essentially with time, did not depend on the environment and did not exceed $0.05 \%$ (in some cases, the elongation of the samples in sodium sulfate solution is slightly higher in comparison with the samples stored in water).

The samples with $\mathrm{Al}(\mathrm{OH})_{3}$ have more dynamic changes in linear dimensions; their elongation depends not only on the exposure time, but also on storage

Table 1. The values of integral intensity of signals on the spectra.

\begin{tabular}{|c|c|c|c|c|c|}
\hline Sample & $1 d$ & Environment & $28 d$ & $3 m$ & $6 m$ \\
\hline \multirow{7}{*}{ Reference } & & \multirow{4}{*}{ water } & $31^{*}$ & 29 & 24 \\
\hline & & & 25 & 24 & 28 \\
\hline & 26 & & 11 & 12 & 13 \\
\hline & 0 & & & & \\
\hline & 0 & \multirow{3}{*}{ Sulfate solution } & 34 & 34 & 28 \\
\hline & & & 20 & 21 & 25 \\
\hline & & & 9 & 10 & 12 \\
\hline \multirow{7}{*}{ with $\mathrm{Al}(\mathrm{OH})_{3}$} & & \multirow{4}{*}{ Water } & 47 & 56 & 51 \\
\hline & & & 51 & 62 & 60 \\
\hline & 100 & & 32 & 14 & 16 \\
\hline & 8 & & & & \\
\hline & 2 & \multirow{3}{*}{ Sulfate solution } & 55 & 62 & 77 \\
\hline & & & 49 & 56 & 44 \\
\hline & & & 30 & 13 & 13 \\
\hline \multirow{7}{*}{$\begin{array}{l}\text { with basic } \\
\text { aluminum sulfate }\end{array}$} & & \multirow{4}{*}{ Water } & 78 & 88 & 66 \\
\hline & & & 38 & 41 & 42 \\
\hline & 82 & & 8 & 9 & 12 \\
\hline & 17 & & & & \\
\hline & 6 & \multirow{3}{*}{ Sulfate solution } & 81 & 86 & 68 \\
\hline & & & 34 & 36 & 40 \\
\hline & & & 7 & 7 & 11 \\
\hline
\end{tabular}

*The first value in cells of the table corresponds to the signal of ettringite (AFt), second and third ones belong to calcium monosulfoaluminate and hydrated aluminates (AFm), correspondingly. 


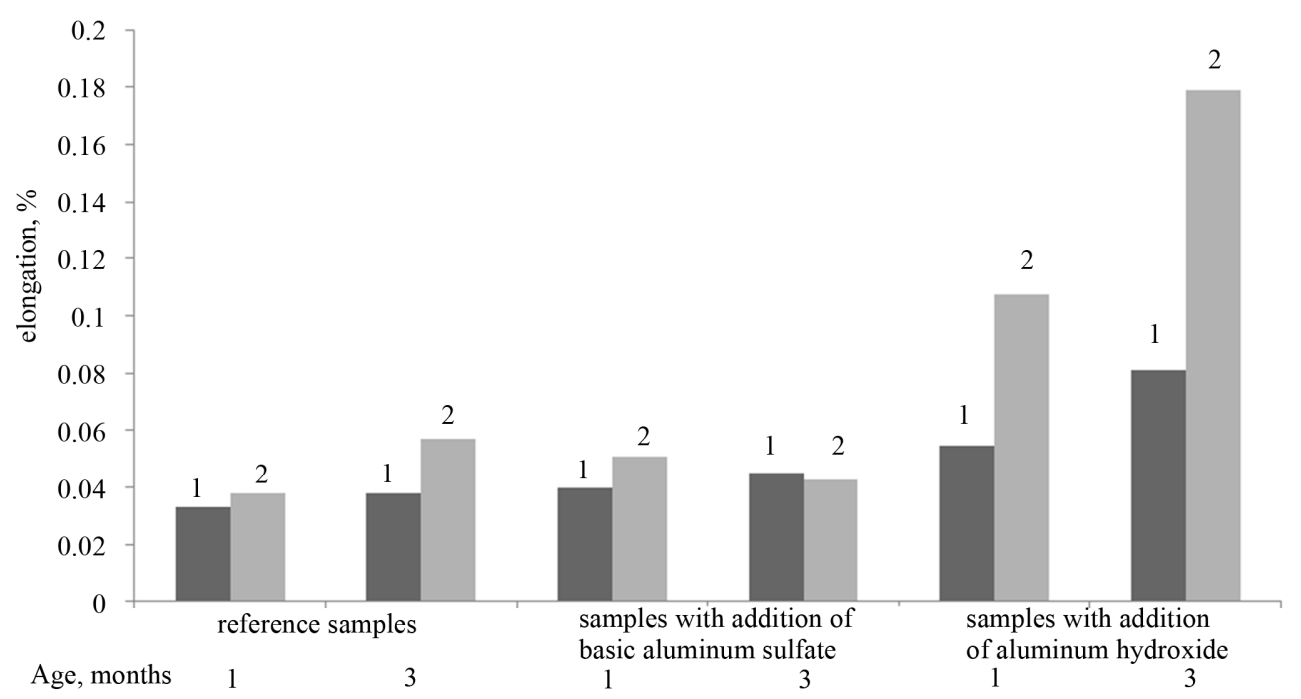

Figure 1. Linear expansion of cement samples in water (1) and sodium sulfate solution (2).

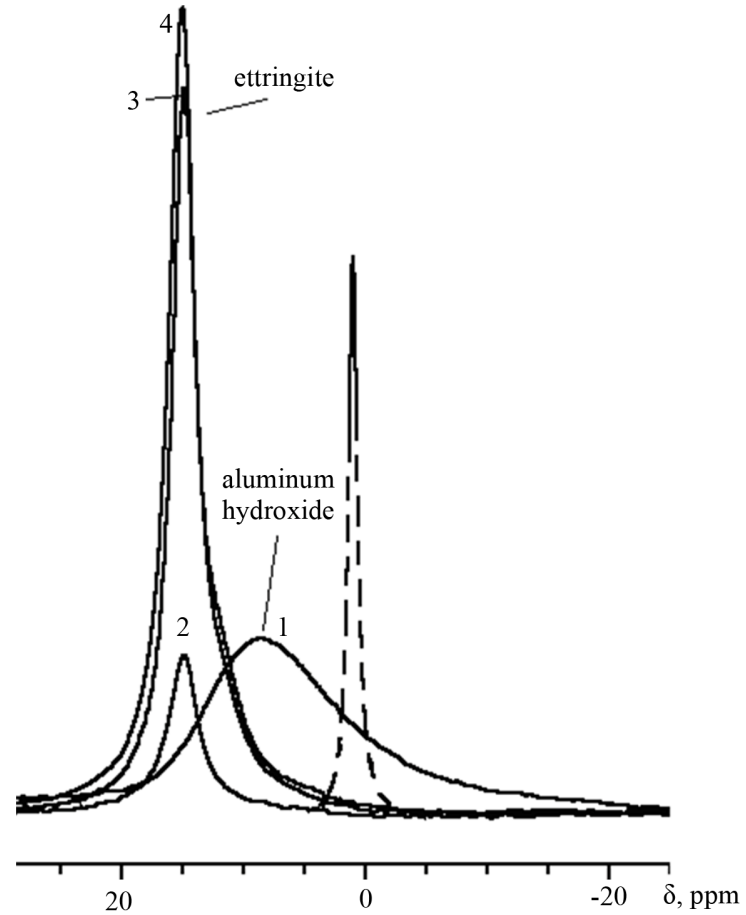

Figure 2. ${ }^{27}$ Al-MAS NMR spectra: initial cement mix with $\mathrm{Al}(\mathrm{OH})_{3}$ (1); cement pastes of 1-day age: reference (2), with $\mathrm{Al}(\mathrm{OH})_{1.78}\left(\mathrm{SO}_{4}\right)_{0.61}(3)$, with $\mathrm{Al}(\mathrm{OH})_{3}(4)$. The dashed line in the figure denotes the signal of aluminum in aqueous solution of basic aluminum sulfate.

environment. Whereas an elongation of samples after 1 3 months of water storing has been $0.05 \%-0.08 \%$, after 3 months of sulfate storing an elongation has reached $0.18 \%$. Moreover, samples with $\mathrm{Al}(\mathrm{OH})_{3}$ stored in sulfate solution have disclosed the first signs of chemical corrosion as early as after 1 month (an exfoliation of

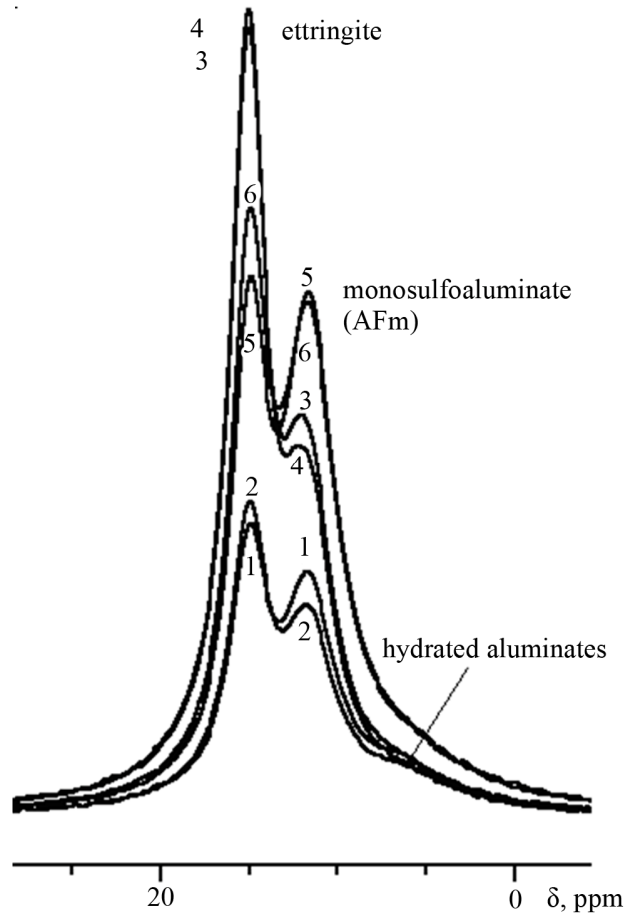

Figure 3. 27Al-MAS NMR spectra of samples of 28-days age: reference $(1,2)$, with $\mathrm{Al}(\mathrm{OH})_{1.78}\left(\mathrm{SO}_{4}\right)_{0.61}(3,4)$, with $\mathrm{Al}(\mathrm{OH})_{3}(5,6)$; water $(1,3,5)$ and sulfate solution $(2,4,6)$ storing. The same goes for Figures 4 and 5.

cement paste). Meanwhile, the samples with basic aluminum sulfate have demonstrated the first signs of failure only after 6 months.

On the spectra of all samples of 1-day age (Figure 2) there is intensive signal at $14.7-15.2 \mathrm{ppm}$ which is characteristic for AFt phase, or ettringite

$\left(3 \mathrm{CaO} \cdot \mathrm{Al}_{2} \mathrm{O}_{3} \cdot 3 \mathrm{CaSO}_{4} \cdot 32 \mathrm{H}_{2} \mathrm{O}\right)$. By this time, both ad- 


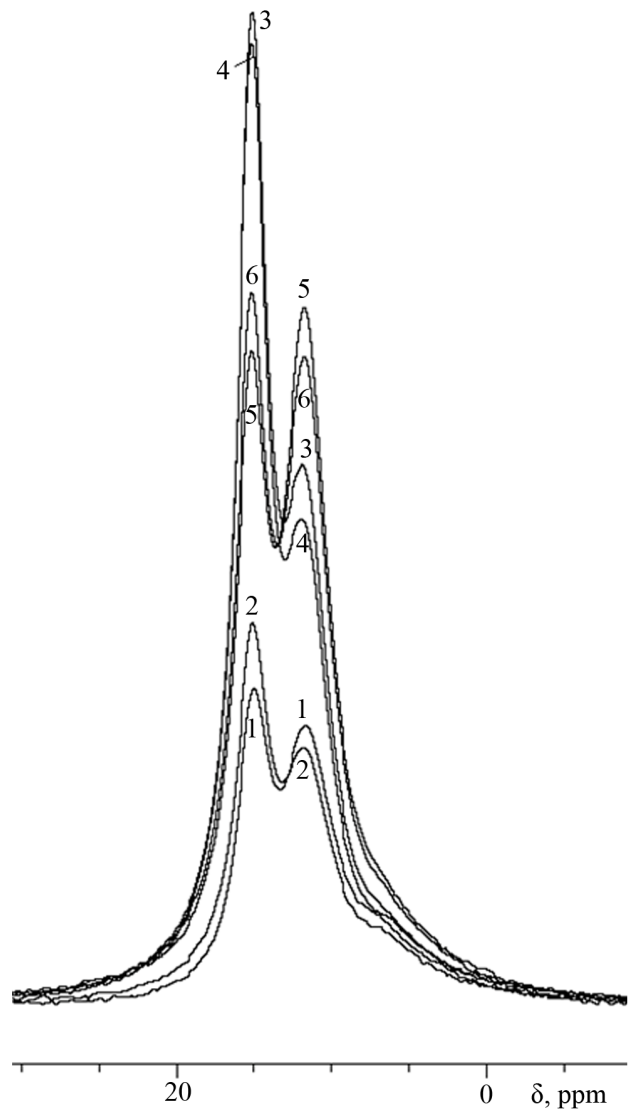

Figure 4. ${ }^{27} \mathrm{Al}$-MAS NMR spectra of cement pastes of 3months age.

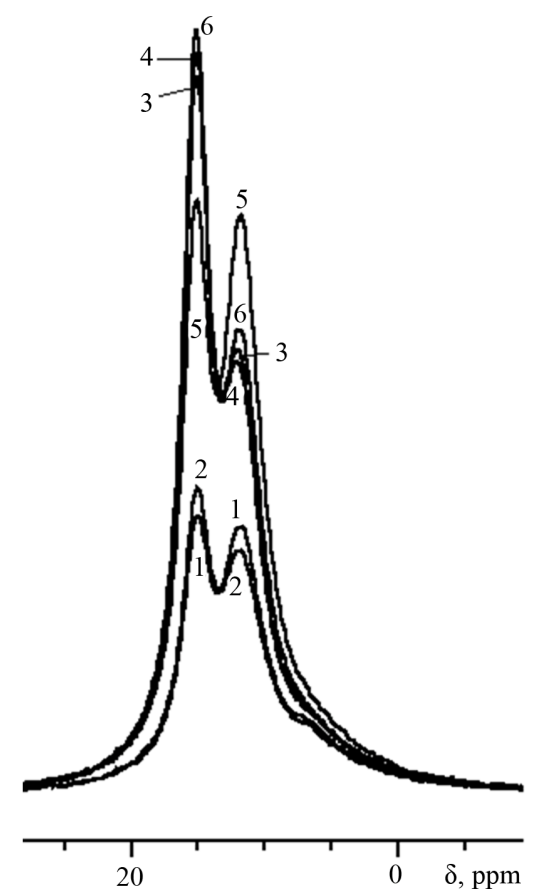

Figure 5. ${ }^{27} \mathrm{Al}$-MAS NMR spectra of cement pastes of 6months age. mixtures have almost completely reacted, as far as there is no sharp signal of basic aluminum sulfate at $0.6 \mathrm{ppm}$; the signal of $\mathrm{Al}(\mathrm{OH})_{3}$ is also completely disappeared. As is known, the content of ettringite in cement paste usually reaches a maximum at this age [8]. Low-observable shoulder to the right of the ettringite signal (11 - $12 \mathrm{ppm})$ on the spectra of samples with admixtures gives evidence of the beginning of the formation of AFm phase, i.e. calcium monosulfoaluminate

$\left(3 \mathrm{CaO} \cdot \mathrm{Al}_{2} \mathrm{O}_{3} \cdot \mathrm{CaSO}_{4} \cdot 12 \mathrm{H}_{2} \mathrm{O}\right)$, due to interaction of ettringite with products of dissolution of aluminate (alumino ferrite) phase:

$$
\begin{aligned}
& 3 \mathrm{CaO} \cdot \mathrm{Al}_{2} \mathrm{O}_{3} \cdot 3 \mathrm{CaSO}_{4} \cdot 32 \mathrm{H}_{2} \mathrm{O}+2 \mathrm{C}_{3} \mathrm{~A}+4 \mathrm{H}_{2} \mathrm{O} \\
& \rightarrow 3\left(3 \mathrm{CaO} \cdot \mathrm{Al}_{2} \mathrm{O}_{3} \cdot \mathrm{CaSO}_{4} \cdot 12 \mathrm{H}_{2} \mathrm{O}\right)
\end{aligned}
$$

The signal of calcium monosulfoaluminate on the spectra of samples of 28-days age (Figure 3) is already quite intense; to the right of this signal the shoulder appears $(6-7 \mathrm{ppm})$ indicating the formation of hydrated calcium aluminates (attributed also to AFm) due to direct hydration of aluminum-containing clinker phases.

At the age of 28 days the differences appear on the spectra of samples of water and sulfate storing. For both, reference samples and samples with admixtures, intensity of ettringite signal is higher for samples of sulfate storing in comparison with ones of water storing. Respectively, the lasts have more intensive signal of calcium monosulfoaluminate.

As can be seen from the spectra of 28-days age, the conversion of ettringite into calcium monosulfoaluminate in samples with $\mathrm{Al}(\mathrm{OH})_{3}$ is more intensive than in samples with basic aluminum sulfate, which is apparently due to the higher total $\mathrm{Al}_{2} \mathrm{O}_{3}$-to- $\mathrm{SO}_{3}$ ratio in the first case. At the age of 3 months (Figure 4), this trend continues for samples of water storing, while in conditions of sulfate storing the ratio between ettringite and monosulfoaluminate in the sample with $\mathrm{Al}(\mathrm{OH})_{3}$ remains practically unchangeable.

By the age of 6 months (Figure 5), the signal of ettringite in sample with $\mathrm{Al}(\mathrm{OH})_{3}$ increases noteworthily, indicating about renewal of ettringite formation in this sample ("secondary" ettringite):

$$
\begin{aligned}
& 3 \mathrm{CaO} \cdot \mathrm{Al}_{2} \mathrm{O}_{3} \cdot \mathrm{CaSO}_{4} \cdot 12 \mathrm{H}_{2} \mathrm{O}+2 \mathrm{Ca}(\mathrm{OH})_{2}+2 \mathrm{SO}_{4}^{2-} \\
& +20 \mathrm{H}_{2} \mathrm{O} \rightarrow 3 \mathrm{CaO} \cdot \mathrm{Al}_{2} \mathrm{O}_{3} \cdot 3 \mathrm{CaSO}_{4} \cdot 32 \mathrm{H}_{2} \mathrm{O}+4 \mathrm{OH}^{-}
\end{aligned}
$$

Secondary ettringite formation in samples with $\mathrm{Al}(\mathrm{OH})_{3}$ becomes possible due to: 1) the presence of sulfate ions coming from the environment solution, 2) $\mathrm{Ca}(\mathrm{OH})_{2}$ formed during cement hydration, and 3) higher content of AFm in comparison with other compositions.

Quantitative interpretation of ${ }^{27}$ Al-MAS NMR data shown in the Table $\mathbf{1}$ is complicated by the fact that the presence of iron ions in the vicinity of aluminum nuclei 
makes at least part of them "invisible" on the spectra [12]. In particular, therein lies the observed discrepancy in quantitative ratio of the signal intensities on the spectra of samples with and without admixtures. As can be seen, for any exposure time including late hydration ages (6 months) the summarized intensity of signals on the reference spectra and the summarized intensity of signals on the spectra with one of the admixtures are in a ratio of about 1:2 (for example, in case of reference sample and sample with $\mathrm{Al}(\mathrm{OH})_{3}$ of sulfate storing at the age of 6 months we have $(28+25+12) /(70+44+13) \approx 1: 2)$. Meanwhile, in accordance with the literature data [8], by the age of 6 months aluminum-containing phases of cement clinker must be completely reacted with water and a substantial part of the aluminum ions must be conversed into six-coordinated form; so, in this case the ratio said above should be 1.6:2 (the amount of four-coordinated aluminum in C-S-H was not considered in calculations).

It can be assumed that aluminum ions going from the aluminoferrite phase into hydration products (AFt and AFm) with retaining Fe-ions in its immediate vicinity cannot be observed on the spectra and, therefore, the contribution of aluminum ions from admixtures and $\mathrm{C}_{3} \mathrm{~A}$ to the values of intensity will be predominant. It is estimated that in Portland cement used in this study aluminum ions are predominantly contained in $\mathrm{C}_{4} \mathrm{AF}(3.2 \mathrm{wt} \%$ $\mathrm{Al}_{2} \mathrm{O}_{3}$ ); respectively, the contribution of $\mathrm{C}_{3} \mathrm{~A}$ is $1.7 \mathrm{wt} \%$ $\mathrm{Al}_{2} \mathrm{O}_{3}$ (the content of aluminum as impurity ions in silicate clinker phases was not taken into account). If we consider aluminum ions from additives and phase $\mathrm{C}_{3} \mathrm{~A}$ only, then in the case discussed above the ratio of the total intensity values should be $1: 2$, which is exactly the same that is really observed in the spectrum.

Thus, participation of $\mathrm{C}_{4} \mathrm{AF}$ in the formation of common products with $\mathrm{Al}(\mathrm{OH})_{3}$ (for example, the formation of ettringite with participation of $\mathrm{Al}(\mathrm{OH})_{3}$ and the followed conversation of ettringite into AFm with participation of $\mathrm{C}_{4} \mathrm{AF}$ ) may give an uncertainty when determining their quantitative ratio on the base of ${ }^{27} \mathrm{Al}-\mathrm{MAS}$ NMR. In this regard, white cements with their negligible iron content are more suitable for model experiments. Such approach can be found in studies using ${ }^{27} \mathrm{Al}-\mathrm{NMR}$, but in practical terms, low-iron cements have a limited distribution and did not completely eliminate the problem of quantitative interpretation of the spectra $[9,12]$.

The analysis of the data presented in the Table 1 can be done with using a value characterizing the ratio of the aluminum amount in ettringite (AFt) to the total amount of aluminum ions in coordination VI included in AFt and AFm:

$$
\frac{\mathrm{Al}^{\mathrm{VI}}(\mathrm{AFt})}{\sum \mathrm{Al}^{\mathrm{VI}}(\mathrm{AFt}+\mathrm{AFm})}
$$

where $\mathrm{Al}^{\mathrm{VI}}(\mathrm{AFt})$ is an intensity of aluminum signal in the ettringite; $\mathrm{Al}^{\mathrm{VI}}(\mathrm{AFt}+\mathrm{AFm})$ is the summarized intensity of signals on the spectrum.

Obviously, this value characterizes the molar contribution of ettringite in the total amount of matter contained in $\mathrm{AFt}$ and $\mathrm{AFm}(\mathrm{AFt} /(\mathrm{AFt}+\mathrm{AFm}))$ and is suitable because it does not depend on sample weight and on the water content. The calculation results are presented in Figure 6.

As can be seen from Figure 6, the value of AFt/(AFt + $\mathrm{AFm})$ is 0 at the beginning of hydration and reaches a maximum (i.e. $\sim 1$ ) by the 1 day of hydration, when the gypsum and admixtures had been consumed, but AFm phase is in the beginning of formation, so, almost all aluminum VI is bonded in ettringite. In the following period, this value takes means less than 1 due to the partial conversion of ettringite into monosulfoaluminate with the participation of $\mathrm{C}_{3} \mathrm{~A}$ and $\mathrm{C}_{4} \mathrm{AF}$ (the contribution of AFm increases whereas the contribution of $\mathrm{AFt}$ reduces). It should be noted that the most significant changes in the content of ettringite occur during the first 28 days, and during the next 5 months the contribution of ettringite continues to decrease very slowly in most cases.

Figure 6 shows that the value $\mathrm{AFt} /(\mathrm{AFt}+\mathrm{AFm})$ is in accordance with the value $\mathrm{Al}_{2} \mathrm{O}_{3} / \mathrm{SO}_{3}$. The lower the value $\mathrm{Al}_{2} \mathrm{O}_{3} / \mathrm{SO}_{3}$ in cement paste, the higher the contribution of ettringite in the sum of $\mathrm{AFt}+\mathrm{AFm}$ (see values $\mathrm{AFt} /(\mathrm{AFt}+\mathrm{AFm})$ at 28-day age, i.e. at the end of the active stage of the conversion of ettringite into calcium monosulfoaluminate).

As already stated, for all studied compositions the contribution of AFt phase in case of sulfate storing is always higher than in case of water storing. This may be due to the fact that ettringite conversion to AFm phases in sulfate solution proceeds slower than in water.

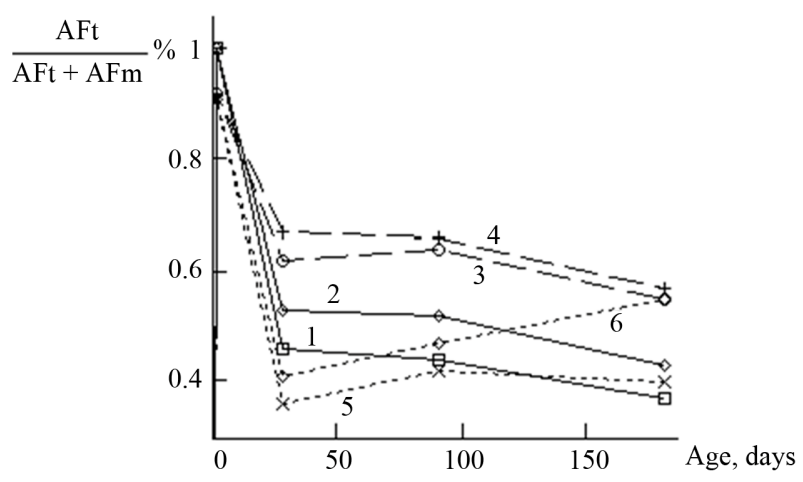

Figure 6. Contribution of aluminum ions of ettringite to the total amount of aluminum ions in AFt and AFm: reference samples $(1,2)$, samples with basic aluminum sulfate $(3,4)$, samples with $\mathrm{Al}(\mathrm{OH})_{3}(5,6)$; water $(1,3,5)$ and sulfate solution $(2,4,6)$ storing. 
Figure 6 shows that in the samples with $\mathrm{Al}(\mathrm{OH})_{3}$ at 1-month age an ettringite contribution reaches the least values in comparison with other samples. At the same time, the accumulation of calcium sulfoaluminate and hydrated aluminates promotes formation of secondary ettringite in sulfate solution as early as 1 month after the start of the test. The data of the Table 1 show that in case of the samples with $\mathrm{Al}(\mathrm{OH})_{3}$ in conditions of sulfate storing, the sustained increase of signal intensity is observed after passing the minimum by the age of 1 month.

The said above is in accordance with the proposition [7] that the use of basic aluminum sulfate leads to the formation of structures more resistant to the sulfate expansion than with using $\mathrm{Al}(\mathrm{OH})_{3}$.

\section{Conclusions}

The sulfate resistance of hardened cement pastes with aluminum-containing admixtures depends on $\mathrm{Al}_{2} \mathrm{O}_{3}$-to$\mathrm{SO}_{3}$ ratio obtained in pastes in the presence of these admixtures. The more the aluminum taking part in the formation of ettringite at early stage of hydration (this is a possibility at low $\mathrm{Al}_{2} \mathrm{O}_{3}$-to- $\mathrm{SO}_{3}$ ratios), the more the stability of the composition in sulfate environment.

An addition of $3 \% \mathrm{Al}(\mathrm{OH})_{3}$ to cement paste increases the $\mathrm{Al}_{2} \mathrm{O}_{3}$-to- $\mathrm{SO}_{3}$ ratio by $\sim 1.3$ times, thereby promoting the formation of low-sulfate aluminum-containing products and reducing sulfate resistance of cement compositions.

In contrast, basic aluminum sulfate $\mathrm{Al}(\mathrm{OH})_{1.78}\left(\mathrm{SO}_{4}\right)_{0.61}$ introduced into cement paste in an amount equivalent to $3 \% \mathrm{Al}(\mathrm{OH})_{3}$, lowers the $\mathrm{Al}_{2} \mathrm{O}_{3}$-to- $\mathrm{SO}_{3}$ ratio by $\sim 1.2$ times. The rate of expansion of hardened cement paste with basic aluminum sulfate in sulfate solution is similar to that of reference sample.

\section{REFERENCES}

[1] R. Myrdal, "Accelerating Admixtures for Concrete. State of the Art," SINTEF Report N SBF BK A07025, Trondheim, 2007, $35 \mathrm{p}$.

[2] G. Saout, B. Lothenbach, A. Hori, et al., "Hydration Mechanism of Quick Hardening Cement Based on OPC Blended with an Amorphous Calcium Aluminate," 18th Internationale Baustofftagung (IBAUSIL) Weimar, 12-15
September 2012, pp. 474-481.

[3] Q. Xu and J. Stark, "The Chemical Action of $\mathrm{Al}(\mathrm{OH})_{3}$ Accelerators in the Early Hydration of Portland Cements," Zement Kalk Gips, Vol. 61, No 3, 2008, pp. 82-92.

[4] A. Brykov, A. Vasilev and M. Mokeev, "Hydration of Portland Cement in the Presence of High Active Aluminium Hydroxide," Russian Journal of Applied Chemistry, Vol. 85, No. 12, 2012, pp. 1793-1799.

[5] K. Natesaiyer and K. Hover, "Chemical Agents for Reducing Solubility of Silica in 1N Sodium Hydroxide," Cement and Concrete Research, Vol. 22, No. 4, 1992, pp. 653-662. http://dx.doi.org/10.1016/0008-8846(92)90017-P

[6] T. Chappex and K. Scrivener, "The Influence of Aluminium on the Dissolution of Amorphous Silica and Its Relation to Alkali Silica Reaction," Cement and Concrete Research, Vol. 42, No. 12, 2012, pp. 1645-1649. http://dx.doi.org/10.1016/j.cemconres.2012.09.009

[7] A. Brykov, A. Vasilev and M. Mokeev, "Hydration of Portland Cement in the Presence of Aluminum-Containing Setting Accelerators," Russian Journal of Applied Chemistry, Vol. 86, No. 6, 2013, pp. 793-801.

[8] H. Taylor, "Cement Chemistry," Thomas Telford, London, 1997, $459 \mathrm{p}$.

[9] I. Richardson, "The Nature of C-S-H in Hardened Cements," Cement and Concrete Research, Vol. 29, No. 8, 1999, pp. 1131-1147.

http://dx.doi.org/10.1016/S0008-8846(99)00168-4

[10] M. Andersen, H. Jakobsen and J. Skibsted, "Characterization of White Portland Cement Hydration and the C-S-H Structure in the Presence of Sodium Aluminate by $27 \mathrm{Al}$ and 29Si MAS NMR Spectroscopy," Cement and Concrete Research, Vol. 34, No. 5, 2004, pp. 857-868. http://dx.doi.org/10.1016/j.cemconres.2003.10.009

[11] A. Mendes, W. Gates, J. Sanjayan and F. Collins, "NMR, XRD, IR and Synchrotron NEXAFS Spectroscopic Studies of OPC and OPC/Slag Cement Paste Hydrates," Materials and Structures, Vol. 44, No. 10, 2011, pp. 17731791. http://dx.doi.org/10.1617/s11527-011-9737-6

[12] A. Rawal, B. Smith, G. Athens, et al., "Molecular Silicate and Aluminate Species in Anhydrous and Hydrated Cements," Journal of the American Chemical Society, Vol. 132, No. 21, 2010, pp. 7321-7337. http://dx.doi.org/10.1021/ja908146m 